\title{
Aa. Vv., «Questes. Bulletin des jeunes chercheurs médiévistes»
}

\section{Mariagrazia Ricci}

\section{(2) OpenEdition}

1 Journals

Édition électronique

URL : http://journals.openedition.org/studifrancesi/3630

DOI : 10.4000/studifrancesi.3630

ISSN : 2421-5856

Éditeur

Rosenberg \& Sellier

\section{Édition imprimée}

Date de publication : 1 décembre 2012

Pagination : 539

ISSN : 0039-2944

\section{Référence électronique}

Mariagrazia Ricci, «Aa. VV., «Questes. Bulletin des jeunes chercheurs médiévistes» », Studi Francesi [En ligne], 168 (LVI | III) | 2012, mis en ligne le 30 novembre 2015, consulté le 07 mars 2021. URL : http:// journals.openedition.org/studifrancesi/3630 ; DOI : https://doi.org/10.4000/studifrancesi.3630

Ce document a été généré automatiquement le 7 mars 2021.

\section{cc)}

Studi Francesi è distribuita con Licenza Creative Commons Attribuzione - Non commerciale - Non opere derivate 4.0 Internazionale. 


\title{
Aa. Vv., «Questes. Bulletin des jeunes chercheurs médiévistes»
}

\author{
Mariagrazia Ricci
}

\section{RÉFÉRENCE}

«Questes. Bulletin des jeunes chercheurs médiévistes», 21, 2011, pp. 135.

1 Le sujet retenu pour ce numéro est Grivoiserie, pornographie, scatologie. Luciano RossI souligne, dans l'Avant-propos (pp.1-9), la nécessité de s'interroger sur le «degré d'intentionnalité» (p.4) des auteurs du Moyen Âge, d'autant plus que, de par sa «fonction symbolique de dénonciation» (p. 6), l'obscénité servait parfois comme moyen pour instruire; d'ailleurs, Rossi rappelle que l'interprétation de l'obscénité dépend surtout de la «force de l'habitude» et de la sensibilité de chacun. C'est dans la même perspective que l'Introduction (pp. 10-34) de Marie DUPUY et Mathilde GRODET questionne l'obscénité en tant que concept lié à la subjectivité des individus et, en l'occurrence, des «mentalités médiévales» (p. 10). D'une part, elles essaient de comprendre, d'un point de vue historique, ce que «bas corporel» (selon l'expression de Mikhaïl Bakhtine, p. 10) pouvait signifier au Moyen Âge; ensuite, elles relèvent les «modes de transgression» (p.19) employés pour contourner les interdits, tels certains éléments rhétoriques (métaphores ou hyperboles) ou certains expédients iconographiques (la représentation de la nudité étant permise, par exemple, pour des thématiques religieuses et sacrées). Francesco MONTORSI (Quelques pistes de réflexion pour une étude scatologique, pp. 35-54) remarque d'abord l'absence d'études consacrées à l'obscénité et à la scatologie dans le domaine français. Sur la base d'un corpus qui comprend des fabliaux (Charlot et le Juif, Trubert, Jouglet, La Crote, Le Vilain Asnier et Porcelet), deux épisodes de la saga de Renart (le Couronnement de Renart et la XVII ${ }^{\mathrm{e}}$ branche) et Audigier, F.M. remarque que dans ces textes les excréments paraissent associés à certains thèmes, tels la ruse et l'humiliation, et aux personnages les plus humbles. Chloé CHALUMEAU (La scatologie dans 'Audigier': de la chanson de geste au fabliau, pp. 55-71) analyse plus précisément ce texte qui concilie la 
structure formelle de la chanson de geste et la matière et le ton des fabliaux. En effet, dans Audigier la matière fécale participe du «rabaissement systématique de ce qui est élevé» (p.60) et, par conséquent, du ton carnavalesque du fabliau. Pierre LEVRON (Mélancolie et scatologie: de l'humeur noire aux vents et aux excréments, pp. 72-88) étudie la scatologie dans la lyrique troubadouresque: l'A. reconnait aux excréments une fonction de prévention, pour l'amoureux, contre l'illusion amoureuse et la mélancolie qui en dérive. Caroline foscallo ('Sor lou lit l'a cochiee et mise, / Puis li solieve la chemise': scènes érotiques et goût du détail obscène dans les fabliaux, pp. 89-104) revient au genre du fabliau: si la grivoiserie est une spécificité du genre, l'A. observe la stéréotypie des descriptions obscènes dans ces textes, qui passe par certaines stratégies rhétoriques telles la métaphore ou l'hyperbole; ainsi, la sexualité dévient un «marqueur de style du genre» (p. 104). Marie-Emmanuelle SIMON (Luxure mise en scène: obscénité, grivoiserie... édification?, pp. 105-122) analyse un corpus de textes incluant quelques farces, les moralités où paraît le personnage nommé Luxure et les mystères comprenant la figure de MarieMadeleine. Si l'A. reconnaît aux farces un but essentiellement comique (sauf dans Raoullet Ployart, qui est porteuse d'une morale), elle remarque la présence de schémas farcesques dans les moralités et les mystères pris en compte: M.-E. S. affirme alors que les passages obscènes devaient assumer dans ces textes une fonction de contre-exemple pour le public qui, tout en s'amusant, en tirait des enseignements édifiants. 